\title{
THE STUDENTS' PERCEPTION OF THE PROFESSIONAL ENGLISH TEACHER AT MA PP NURUL HAQ BENTENG LEWO KABUPATEN SIDRAP
}

\author{
Bakri M. Alik ${ }^{1}$ Nanning $^{2}$ \\ Ssmb159@gmail.com \\ English Program, Tarbiyah Faculty, State Islamic Institute of Parepare ${ }^{12}$
}

\begin{abstract}
Everyone has the different perception or arguments about an object around them. So as students, they also have perception about their teacher especially to the English teacher. In every school there are some categories of the teachers namely the good teacher, bad, friendly and the professional teacher. As the professional teachers they should have or mastery four competencies namely, pedagogical competence, professional, personality and social competence. This study was aimed to know aboutthe professional English teacher and the students' perception of the professional English teacher.The objective of this research was to get the empirical data about the professional teacher and students' perception. The population of the research consisted of sixty students of the first grade, the second grade and the third grade. The sample of the research consisted of 60 students. The research method used in the research was a qualitative and quantitative method (Mix-method) by using descriptive design.The data was collected through observation and questionnaire.Based on the calculation, the result of the dataanalysis showed that the students' perception of the professional teacher got a good perception that it wasincluded high category. In other words, the teacher at MA PP NurulHaqBentengLewoKabupatenSidrap was included in the professional teacher.
\end{abstract}

Keywords: Perception, Professional Teacher. 


\section{Introduction}

In the current era of globalization, education is a matter of great concern. Education has a role in shaping the good or bad of the human person. Without education humans cannot develop, advance, prosper and be happy in accordance with the purpose of a good life. The process of development and human education are not only influenced by the educational processes that exist in the formal education system, but also depend on education that is outside the formal environment. Therefore education is very important in the lives of people, nations and countries in shaping a better generation in the future.

Education is a process of character building, adding insight, developing potential and skills in each student to be able to understand an object and be able to make people think critically. In education there are several important elements one of which is the teacher. Teacher are educators and instructors who have the responsibility in educating, teaching, training, guiding, and giving encouragement to students starting from the lowest level to the higher level. A teacher has a very important role in developing the potential of students to become better. So in this case the teacher is required to be more professional in carrying out their duties for the creation of a better generation. In the world of education a teacher must have the ability or competence in order to have the expected performance so that it can realize the goals of education. Competence that is owned by every teacher will show the quality of teacher in teaching. The competence will be manifested in the form of mastery of knowledge and professionals in carrying out its function as a teacher.

In this case, four competencies must be possessed by a teacher to achieve the title of a professional teacher, namely pedagogical, professional, personality, and social competencies. 
Pedagogical Competence is the ability to understand students, design and implement learning, evaluate learning outcomes, and develop students to actualize the various potentials they have. Pedagogic can be interpreted as ability in the process of interaction that occurs continuously and interrelated between scientific knowledge and student development. This competency is one of the competencies that must be possessed by a teacher in teaching because this can determine success in the learning process and the results to be achieved by students.

Professional competence is one of the competencies that must be possessed by every teacher in education. Professional competence is competence or ability related to the completion of teacher tasks. As a professional teacher, a teacher should master the material and content that will be taught to students. According to Hamzah B. Uno, professional competency is a set of abilities that must be possessed by every teacher to carry out their teaching assignments well and achieve success (Uno, 2007).

Personality competence is a personality ability that is steady, noble, wise, and authoritative as well as being an example of students, steady, stable, mature, wise and wise, evaluating their performance, and developing themselves continuously. According to Longman, personality competencies are aspects of the behavior, feelings, beliefs, thoughts, actions, and attitudes of a teacher that are seen as his trademark (Richards, et al, 1992).

Social competence is one of the abilities that a teacher must have in communicating and interacting effectively with students both inside and outside the school environment.

So, a professional teacher must be able to master and implement the four competencies. It seems like to the teacher in MA PP Nurul Haq Benteng Lewo Kabupaten Sidrap is also expected to be able to carry out the learning process 
well. However, the results of preliminary observations show and give the fact that the situation of students in these schools tends not to be interested in following the learning process specifically in the field of English language studies. While one of the successes of a teacher in teaching can be measured in terms of students' understanding of the material or field of study that has been taught. So that researchers are interested in studying the issue in depth by allowing students to convey their perceptions to teacher in the school.

Perception is the act of compiling, recognizing, and interpreting sensory information in order to provide an overview and understanding of the environment. Perception includes all signals in the nervous system that are the result of physical or chemical stimulation from the sensing organs. This perception exists because humans who have the cognitive ability to process information obtained from the environment around them with the intellect they have, then humans make judgments about what they see or feel and think to decide what they want to do later.

Perception is astimulation that is received by someone through its senses. According to Oxford; perception is the way of someone to notice things, especially with the senses (Oxford, 2011). Furthermore, According to Longman; perception is the recognition and understanding of events, objects, and stimuli through the use of senses (sight, hearing, touch, etc.) (Richards, et al, 1992). According to Longman Dictionary, there are three types of perception:

\section{Visual Perception}

Visual perception is the ability to interpret the environment that is associated with light. The results of visual perception are often referred to as a vision. The perception about visual information or stimuli is accepted by the eyes. The eyes are almost spherical and have a diameter of 2-2, $5 \mathrm{~cm}$, are a set of structures that allows the transformation of the light into a code that the brain can understand. 


\section{Auditory Perception}

Auditory perception is obtained through the sense of hearing which is the ear. Hearing can be defined as the ability to recognize the sound. Auditory perception needs a listener to detect the different kinds of acoustic signals, and to judge differences between them according to differences in such acoustic characteristics as their frequency, amplitude, duration, an order of occurrence, and rate of presentation.

\section{Speech perception}

Speech perception is the process by which the sounds of language are heard, interpreted and understood. Furthermore, Gareth Gaskell and Jelena Mirkovic stated that Speech perception is a product of auditory processing that speech perception can be understood within an auditory perceptual framework. Speech perception necessarily entails the processing of the talkers' intended articulations and that requires the processing of motor representation (Gaskell and Mirkovic, 2017).

The teacher is an educator who has dedicated himself to teaching science in educating, directing and training students to be able to understand every science that has been given or taught. The teacher has an important role in the transformation of knowledge to the students. The teacher is reliable in the field and has a high responsibility and professionalism that is appropriate to the task in accordance with the law of Republic of Indonesia No. 14/2005 article 1, paragraph 1 mentioned that "The teacher is a professional educator with the main task of educating, teaching, guiding, directing, training, assessing and evaluating students in early childhood education through formal education, basic education, and secondary education (DepartemenPendidikan Nasional, 2005). 
A professional teacher is someone who has the ability, skills, and expertise in educating and guiding students in developing the potential that exists in themselves. As teacher, we may have direct control only over what we bring to the classroom: our knowledge, skills, experience, and beliefs about teaching (Haager, 2010). Professional teacher always develop themselves towards knowledge and explore their expertise, and then professional teachers are diligent in reading literature with no feeling of loss in buying books related to the knowledge being cultivated.

Competence is the ability and authority of teachers in implementing the teaching profession. Based on these provisions, it can be seen that teacher competency is a requirement that must be met to achieve the title as a professional teacher. This is by Law No. 20 of 2003 concerning the national education system which explains that educators must have academic qualifications and competencies as agents of learning, healthy and spiritual, and can realize the goals of national education. Four competencies must be mastered by professional teacher. As for the four competencies, namely: pedagogical, professional, personality and social competencies (DepartemenPendidikan Nasional, 2003).

Pedagogical competence is a competency that must be mastered by the teacher. In essence, pedagogical competence is an ability possessed by a teacher in processing learning. This competency is a distinguishing characteristic between the profession as a teacher and other professions. Pedagogic ability can also determine the level of success of the teaching and learning process.Pedagogical abilities that must be possessed by the teacher:

1. Planning the teaching and learning process.

2. Implement and manage the teaching and learning process.

3. Assessing the progress of the teaching and learning process. 
4. Mastering lesson material.

Professional competence is the ability to master material broadly and deeply. Professional abilities that must be possessed by teachers include:

1. Mastering the foundation of education.

2. Mastering teaching material.

3. Developing teaching programs.

4. Carrying out teaching programs.

5. Assessing the result of teaching-learning processes that have been implemented.

Personality is a combination of basic nature with human attitude influenced by the surrounding environment. According to Eysenk H.J personality is the sum total of actual or potential behavior-pathern's of organism as determine by beredity and environment; it originates and develops through the functional interaction of the four main sectors in to which these behavior-patterns are organized $=$ the cognitive sector (intelligence), the conative sector (character), the affective sector (temperament), and the somatic sector (constitution) (Eysenk, 1947). Furthermore, Tomas Chamorro-Premuzic \& Adrian Furnham stated that personality is referred to as stable patterns of behaviors or traits that predispose an individual to act in specific (more or less consistent) manner (Premuzic\&Fumham, 2005).Personality abilities that must be possessed by teacher include:

1. Developing personality.

2. Interacting and communicate.

3. Carrying out guidance and counseling.

4. Carrying out school administration

5. Carrying the simple research for teaching purposes. 
Social competence is an ability possessed by a teacher in communicating and interacting effectively with the school environment or in the surrounding environment. According to Margaret Semrud-Clikeman Social competence is an ability to take another's perspective concerning a situation and to learn from experience and apply that learning to the ever-changing social landscape (Clikeman, 2007).Social abilities that must be possessed by teachers include:

1. Being inclusive, acting, objectively, and do not discriminating because of consideration gender, religion, race, physical condition, family background, and socioeconomic status.

2. Communicating effectively, empathically, politely with fellow educators, educational staff, parents and community.

3. Adapt to places of duty that have socio-cultural diversity.

4. Communicating with the professional community itself and other professions verbally and in writing.

\section{Method}

This research applied descriptive method. It being qualitative and quantitative approaches by using descriptive design.

The location of the research will take at MA PP Nurul Haq Benteng Lewo Kabupaten Sidrap. The research used qualitative research that has several times to collect and analyze data. This research will be doneless more than one month for collecting data.

The population of the research would be the students at MA PP Nurul Haq Benteng Lewo Kabupaten Sidrap which consists 60 students of three classes: first grade, second grade, and third grade. The sample of the research took all of the studentsat MA PP Nurul Haq Benteng Lewo Kabupaten Sidrap. The sampling was 
used in this research that was called total sampling. The instruments were used in this study were questionnaire and observation.

\section{Result}

To find out the result of this research, the researcher has done the observation and giving the questionnaire to the students at the english program began of the third until the ninth semester which consists of two hundreds and fourty students.

Based on the observation that the researcher has been done by about the teachers at MA PP NurulHaqBentengLewoKabupatenSidrap. The researcher found the result of the observation as follow:

In the learning process at MA PP Nurul Haq Benteng LewoKabupatenSidrap, the researcher have observed several things towards English teacher as follows:

First, the teacher manages and implements the learning process well. Because it can be seen from the readiness of the material or learning material and the media used before starting the learning process. In the implementation of learning the teacher is able to apply or implement material that is appropriate to the circumstances of the students. So that students feel comfortable in learning without any pressure or coercion. Then not only that, the teacher is also able to use learning media such as LCDs, laptops, speakers and others - as well as in applying approaches, methods, strategies and techniques in learning. In the teaching and learning process can not be separated from an assessment conducted with the intent and purpose to determine the level of understanding of students towards the material being taught. The assessment is carried out by the teacher through various evaluation processes such as oral, written and in the form of practical tests. 
Second, the mastery of the teaching material that will be taught to students is an indicator of professional competence. The English teacher at the school is able to know the state of students learning so that it is quite easy to determine approaches, methods, techniques and learning strategies that are appropriate for students, so that students can learn well and cause a feeling of comfort or enthusiasm in learning. Likewise in terms of insight and understanding of the teacher of the material that is delivered or taught can also support the creation of a good learning process. Because seen when the teacher delivers and explains the material using language and examples that are easily understood by students and supported by the teacher's ability to use or operate various media in the learning process.

Third, developing student personality to be better as it should be is one indicator in personality competence, talking about personality means that it cannot be separated from the words attitude, character and behavior of a person towards a particular situation. The role of a teacher is very important in shaping and developing the personality of students, because the teacher is the closest person as well as a parent for students at school. Similar to the English teacher at MA PP NurulHaqBentengLewoKabupatenSidrap, the teacher is trying to shape and develop the personality of the students so that they are better behaved, behave and are also positive towards every problem encountered, by always connecting all learning materials related to religious knowledge and accompanied by good advice at the end of learning or meeting in class. So students not only learn about English but also gain knowledge about religion through the advice that has been given.

Furthermore, the ability to interact and communicate well is very important for a teacher, because without good interaction and communication, 
teaching and learning activities will not run well and this is also a part or indicator of social competence. Theteacher at MA PP NurulHaqBentengLewoKabupatenSidrap especially the English teacher has a good relationship with the students in interacting and communicating. Because it can be seen from the way the teacher spoke intimately and politely to his students. Likewise, interactions and communication that occur within the school environment, especially with staff or work colleagues can be seen from their cohesiveness and cooperation in teaching, guiding and educating students to be better as they should. Likewise, in the interaction and communication that occurs between the teacher and parents of students when holding a meeting is related to the development and shortcomings of students in the subjects they bring.

Finally, the teacher does not distinguish students from one another in attitude in other words there is no difference or special treatment between students who have parents with low or high economics, the culture owned by students and their social status. All students have the same rights to study. Because it can be seen when the teacher gives material, assesses, evaluates and interacts and communicates with students.

The result of the questionnaire can be seen on the table of tendency category data as follows:

Table 4.15

\begin{tabular}{|c|c|c|c|c|}
\hline NO & Score interval & Category & f & Percentage \\
\hline 1 & $14-24$ & Very Low & 0 & 0 \\
\hline 2 & $25-35$ & Low & 2 & $3.34 \%$ \\
\hline 3 & $36-46$ & High & 34 & $56.66 \%$ \\
\hline 4 & $47-57$ & Very High & 24 & $40 \%$ \\
\hline
\end{tabular}

Based on the percentage above showed that the students' perception of the professional English teacher including high category with percentage 56.66\%. It 
Means the English teacher at MA PP NururlHaqBentengLewoKabupatenSidrap was a professional teacher according to their students' perception.

Based on the description of the data through questionnaire, each items of the questionnaire are analyzed from the first item until fourteenth or the last item. The analysis data of each item are based on the result of the students' perception or their answer through the questionnaire that have been given by the researcher. The mean score of the questionnaire result was 44.6 while the percentage of this result was $56.66 \%$. The result of questionnaire showed that the students' perception was high category.

Students' perception is the arguments or opinion about their environment especially to the English teacher at MA PP NurulHaqBentengLewoKabupatenSidrap. Perception is the act of compiling, recognizing, and interpreting sensory information to provide an overview and understanding of the environment. Perception includes all signals in the nervous system, which are the result of physical or chemical stimulation of the sensing organs.

Besides giving questionnaire the researcher also did observation when the teacher teach their students in the class and the out class to be able to know about the professional teacher in applying or implemented the fourcompetencies of teacher. Based on the findings through questionnaire and observation, it has been found a lot of students give a good perception to their teacher's competence. Therefore, the teacher at MA PP NurulHaqBentengLewoKabupatenSidrap was professional in teaching their students.

\section{Conclusion}

The four competencies are very important to the teacher. As the professional teacher should be understandable about the pedagogical competence, 
professional, personality and social competence. Based on findings and discussion have been explained in the previous chapter. The researcher concluded that theEnglish teacher at MA PP Nurul Haq Benteng Lewo Kabupaten Sidrap was really professional, because they could be apply four competencies well. All of students give a good perception of theprofessional English teacher at MA PP NurulHaqBentengLewoKabupatenSidrap that means the teacher was professional. It can be seen from the result of the questionnaire who have been given to the students with percentage $56.66 \%$ including high category.

\section{References}

Arikunto, Suharsimi. 1998. Prosedur Penelitian. Jakarta: Rineka Cipta

Clikeman, Margaret Semrud. 2007.Social Competence in Children. Michigan: Springer

Departemen Pendidikan Nasional. 2003. Undang-Undang Nomor 20 Tahun 2003, Tentang Sisdiknas. Jakarta: Depdiknas.

- Pendidikan Nasional. 2005. Undang-Undang Nomor 14 Tahun 2005, Tentang Guru dan Dosen. Jakarta: Depdiknas.

Folit, Denis F. 2003. Nursing Research. Philadelphia: Lippincott and Wilkins.

Gaskell, Gareth and Jelena Mirkovic. 2017.Speech Perception and Spoken Word Recognition. London and New York: Routledge Taylor and Francis Group.

Haager, Diane et al., 2010. How to Teach English Language Learners. America: Jossey Bass.

J, Eysenk H. 1947Dimension of Personality. London: Routledge And Kegan Paul.

Joseph,Stephen. 2017. Student Perceptions of Teacher Professional Attire, Journal: The University of Trinidad and Tobago: Trinidad and Tobago.

Kurniati, Intan. 2017.The Student's Perception of Their Teacher Teaching Style'sJournal: State University of Medan: Medan.

Oxford Learner's Pocket Dictionary, $4^{\text {th }}$ ed. 2011. Oxford: Oxford University Press. 
Premuzic, Tomas Chamorro\& Adrian Furnham. 2005.Personality and Intellectual Competence. London: Lawrence Erlbaum Associates.

Richards et al.,1992. Longman Dictionary of Language Teaching and Applied Linguistics. Cambridge: Cambridge Univ.Press.

Sugiyono. 2016. Metode Penelitian Manajemen. Bandung: Alfabeta.

Uno, Hamzah B. 2007. Profesi Kependidikan: Problema, Solusi \& Reformasi. 